\title{
CHAPTER 4 \\ GEOMARKETING AS A TOOL FOR ENSURING THE COMPETITIVE DEVELOPMENT OF AGRICULTURAL ENTERPRISES
}

\section{Hranovska V. H.}

\section{INTRODUCTION}

The active phase of the fourth industrial revolution, the integration of agricultural enterprises into the global competitive environment requires the formation of new strategic approaches to managing their economic development and production and marketing activities. The managerial decision-making time, the economic feasibility of such decisions, adaptability to the conditions of the operating environment directly affect the competitive status of the entity in the market. The activities of agricultural establishments are gaining new productiveeconomic essence and requiring all participants in economic relations to be prepared for transformations, maximize adaptation to variability and resilience to global challenges. In such circumstances, the need to formulate a new paradigm for ensuring a competitive development of agrarian enterprise, aimed not only at activating innovative vectors, but also at creating a balanced model of their economic development, becomes essential. This business model should stimulate and provide increase of production capacities, diversification of production, search for the newest forms of organizational and economic alternatives and the newest approaches to the formation of economic mechanisms, including marketing ones.

Current trends in the development of environment, such as globalization of activities, integration into the global economic space, liberalization of trade conditions while increasing consumer demands and the degree of their influence on the activity of business structures, innovative challenges, affect not only technological but also managerial and organizational aspects functioning of organizational and legal agencies, causing the emergence of new forms of entrepreneurship and improvement of existing ones. Formation and strengthening of the competitive position, adaptability and flexibility of the economy of the enterprise becomes the result of strategic interaction of external market and internal production and management factors. At the same time, it is 
important to use modern tools to ensure the competitive development of agricultural enterprises in the context of the need to promote their products to world markets quickly and maintain and expand the market segment.

\subsection{The current state and features of forming a balanced model of competitive development of agricultural enterprises}

The development of market relations at the present stage is performed when the combination of complex and contradictory processes of business globalization, limited resources, accelerated technological innovations, resulting in increased competition. The current business conditions of agricultural enterprises are characterized by aggravation of competition, as well as increasing uncertainty and high dynamics of transformation of the environment. An effective tool for managing the economic activity of agrarian enterprises, ensuring the realization of tasks and priorities of economic development in the conditions of changes of macroeconomic nature and market situation, is a competitive strategy. In the context of dynamic changes of the external and internal environment of functioning of agricultural enterprises, given the complexity of economic relations between the subjects of economic relations, it is important to manage the competitive development of business structures on the basis of the formation of competitive strategies. Ensuring a competitive development of business entities requires the improvement of the system of management of this phenomenon in the enterprise in order to ensure the most efficient distribution and use of production facilities and focus them on meeting the potential requirements of consumers in competitive products. Creating an effective enterprise competitive management system requires a clear, scientifically justified methodological apparatus, the core of which should be a competitive enterprise strategy, created on the basis of in-depth economic analysis and forecasting, with the obligatory construction of various behavior models of both the whole system and its individual subsystems.

The formation of a system of strategic management of agricultural companies, including through the implementation of models of ensuring their competitiveness in a globalized world, requires the development of an adaptive strategy for ensuring competitiveness, which would take into account the specificities and needs of agricultural enterprises and is a priority task in their management. 
In competitive conditions, the dominant of their formation is the competitive strategy of the enterprise as a result of strategic management measures. Accordingly, the orientation of the agricultural enterprise and its economic behavior will be to respond to the changing conditions and challenges of the environment, adjusting the fulfillment of its tasks. Today, effective adaptation of an agricultural enterprise is a prerequisite for maintaining its competitiveness, a way of surviving in a changing market environment, and a form of achieving a certain strategic goal. The managerial and organizational structures of the enterprise are directly dependent on the rapidly changing environmental factors, the implementation of measures to respond to these changes, the use of adaptive competitiveness management for the internal environment and its components to adjust to external changes.

In the context of globalization, an important factor is the strengthening of competitiveness in all types of economic activity, which enables the enterprise to reorient itself in a timely manner and to correlate its strategic set in accordance with the new operating conditions. It is important to realize that there is a direct dependency and an inseparable relationship between the degree of adaptation of agricultural enterprises and competitiveness. Thus, the latter contributes to the rapid and efficient adaptation of agricultural establishments to changes in the environment and to the conditions of globalization, and the development of globalization processes allows to maintain a competitive level. Effective strategic management of the company helps to maximize the positive effect of business. In the conditions of competition the degree and intensity of managerial decisions influence on the final result of production activity increases, namely: financial and economic condition of the enterprise, financial stability, size of the market segment, degree of intensity of competition, resistance to change. One of the basic principles of competitive development and success of enterprises in the market is balance in the business system. The economic efficiency is achieved providing the systematic and successful combination of the following components: use of high-tech equipment, innovative technologies; increase of employees' readiness for training and acquisition of relevant competences, skills and working knowledge; improvement of the enterprise management system and effective sales policy. Today, the only resource strategies and improvement of the enterprise's production program do not fully ensure competitive development and economic growth. Therefore, the emphasis in the 
management of agrarian enterprises is shifting towards improving the enterprise's marketing policies and marketing strategy.

The problems and the concept of sustainable socio-economic development and effective management have been considered by a number of scientists, among them there are N.V. Bahrov ${ }^{1}$, O.H. Bilorus ${ }^{2}$, Ye.M. Borshchuk ${ }^{3}$, I.M. Vakhovych ${ }^{4}$ and Z.V. Herasymchuk, B.M. Danylyshyn ${ }^{5}$, and others. However, there is a need to discuss the issue of effectively stimulating the management of agricultural enterprises based on the use of management innovations ${ }^{6}$. Geomarketing should be an effective tool in the circumstances of increased geoeconomic competition. Our study is devoted to clarifying the essence, features and tools of geomarketing as an approach to stimulating effective management of agricultural sector entities.

Marketing activities in the field of agricultural production due to some features related to the natural conditions of production, yield and intensity of use of agricultural land; the importance of the manufactured goods, which defines the special requirements for its production, storage and transportation; discrepancy between the time of production and its consumption; seasonal nature of production; a variety of forms of ownership in the agricultural sphere of production; the presence of various organizational and legal forms of management; duration of the cycle of production and consumption of agricultural products. The above adds complexity to making effective marketing decisions in competition, satisfying consumer requests for product quality. Agromarketing has a high sensitivity and percipiency to external changes compared to other marketing systems. The relatively low level of scientific development in the field of marketing of agricultural enterprises should also be noted.

\footnotetext{
1 Bagrov N.V. (2002). Regionalnaya geopolitika ustoychivogo razvitiya [Regional geopolitics of sustainable development]. Kiev: Lyibid, 256 p.

2 Bilorus O.H., Matseiko Yu.M. (2005). Hlobalna perspektyva i stalyi rozvytok: Systemni marketolohychni doslidzhennia [A global perspective and sustainable development: system market research]. Kyiv: MAUP, 492 p.

3 Borshchuk Ye.M. (2007). Osnovy teorii stiikoho rozvytku ekoloho-ekonomichnykh system: Monohrafiia [Fundamentals of the theory of sustainable development of ecological and economic systems: Monograph]. Lviv: Rastr -7, 435 p.

${ }^{4}$ Herasymchuk Z.V., Vakhovych I.M. (2002). Orhanizatsiino-ekonomichnyi mekhanizm formuvannia ta realizatsii stratehii rozvytku rehionu: Monohrafiia [Organizational and economic mechanism of formation and implementation of the regional development strategy: Monograph]. Lutsk: LDTU, $248 \mathrm{p}$.

5 Danylyshyn B. (2008). Formuvannia tsilisnoi natsionalnoi hospodarskoi systemy: sotsiolohoekonomichni aspekty [The formula of the cospilial national hospodar system: socio-economic aspects]. Visnyk NAN Ukrainy, no. 7, pp. 3-11.

6 Makhnusha S.M Pidkhody do stymuliuvannia staloho rozvytku rehioniv na zasadakh heomenedzhmentu ta heomarketynhu [Approaches to stimulating sustainable development of regions based on geo-management and geomarketing]. URL: http://zavantag.com/docs/427/index2023587.html?page $=18 \# 977151$
} 
At present, agrarian marketing is a management concept that provides market orientation of the production and marketing activities of the enterprise, and the basis of making the managerial decisions are not only the capabilities of the producer, but primarily the needs of the agroindustrial market, existing and potential needs of consumers and buyers of agricultural products. The modern concept of marketing is that all activities of the company are based on knowledge of consumer demand and its changes in the future. The marketing system makes the production of goods functionally conditional upon demand and requires the production of goods in the range and quantity that the consumer needs. That is why agrarian marketing, as a set of methods of studying the markets, is additionally still focusing its efforts on the creation of effective sales channels and carrying out complex demand formation.

\subsection{Formation of marketing strategy by agricultural establishments taking into account the spatial component}

The use of spatial data allows to quickly make up the objective need to manage spatially separated objects, to obtain information about the competitive environment, consumers and markets and infrastructure of the territories when implementing a marketing policy for agricultural enterprise. Thus, the importance of geomarketing as a key component in decision making in the management of agricultural enterprises is increasing.

The spatial component of making managerial decisions allows you to take into account geomarketing, which is a derivative of marketing, but has its own unique tools, functions and goals. Today, geomarketing researches are an integration of marketing and geographic tools to create a new economic tool for managing the enterprise's production and marketing activities to ensure its economic growth and enhance competitiveness. The use of geoinformation technologies allow the enterprise to effectively manage the infrastructure of the territories, to improve the logistics of sales and to use the spatially-distributed objects and resources as efficiently as possible.

The environment of geomarketing is characterized by the following: the contradictory nature of the Ukrainian reforms and their incompleteness; imperfection of market relations, when the basis of their formation is orientation to the end product, and not to the needs of the consumer in high-quality and ecologically safe, organic agricultural products; low level of training and lack of marketers who have the competencies and skills to work in the agricultural sector; non-regulation 
of the legal framework on consumer protection ${ }^{7}$. It should be noted that the current state of the economy not only creates problems in the field of geomarketing, but also opens up new opportunities. Agrarian enterprises find new, non-standard approaches to addressing the needs of consumers 8 .

The experience of the countries with developed market economy shows that science, knowledge-intensive technologies, active innovation activity are the driving force of production development in all branches of economy, about $85 \%$ of the gross domestic product is obtained at the expense of new knowledge that has been transformed into knowledgeintensive technologies. According to the World Bank, the national wealth of developed countries is only $5 \%$ of natural resources, $18 \%$ of material production capital, and $77 \%$ of knowledge and the ability to use them rationally ${ }^{9}$. The innovation component is a key component that ensures progress and competitive innovation. Therefore, the current realities of the market formation of the agricultural sector of the economy require improvement of the practical and methodological component of spatial management of economic activity. On this basis, the marketing strategy should be shaped taking into account both the economic and the spatial components. The vector of competitiveness of the enterprise significantly shifts towards innovative provision of organization of production and marketing activity, including economic space of the business entity.

In recent years, logistical research and obtaining information on the geographical structure of the market have been important in shaping the enterprise's marketing strategy ${ }^{10}$. At the same time, strengthening the intellectual and informational component of the strategy of development of agrarian enterprises will allow to qualitatively increase their marketing policy and to ensure competitive development. Another positive aspect of the application of the geoinformation component in an enterprise strategy is the creation of a unified information environment for the management of spatially distributed resources in order to ensure

\footnotetext{
Butenko N.V. Osnovy marketynhu: pidruchnyk [Marketing Basics: Tutorial]. URL: http://books.efaculty.kiev.ua/mrk/3

${ }^{8}$ Iurchenko O.A. (2010). Perevahy vykorystannia marketynhu na pidpryiemstvakh APK [Advantages of using marketing at agricultural enterprises]. Marketynh v Ukraini, no. 2, pp. 22-30.

${ }^{9}$ Mazniev H.Ie. (2011). Heoinformatsiini tekhnolohii v ahrarnomu vyrobnytstvi [Geoinformation technologies in agricultural production]. Ekonomika APK, no. 4, pp. 130-136.

${ }^{10}$ Nesi P. Geographical localization of web domains and organization addresses recognition by employing natural language processing, Pattern Matching and clustering. Engineering Applications of Artificial Intelligence Mining the Humanities: Technologies and Applications. Vol. 51, May 2016, pp. 202-211.
} 
economic growth and competitive development. The current market transformations determine the level of agricultural enterprises development due to the achieved level of competitive potential, which is linked to the presence of sectors of the economy that have high technology, developed transport infrastructure, the availability of cheap labor and so on. Unlike other economic categories, the competitive potential of an enterprise has several features. Firstly, it can only be detected and evaluated in the presence of real or potential competitors. Secondly, the competitive potential of the enterprise depends on the productivity of the use of resources involved in the production process. Thirdly, the level of competitive potential of an enterprise depends on the level of competitiveness of its components, as well as on the overall competitiveness of the industry and the country. To obtain the results of assessing the level of competitive advantage, it is necessary to strengthen certain components of the enterprise's potential, which will be able to provide a real reflection of the situation in the macro and microenvironment. Many approaches are used to research the competitive potential of agricultural enterprises, but researchers are often limited to some of them, which characterize their individual aspects. At the same time, the use of geomarketing tools should become an integral part of the comprehensive use of methods and approaches that will identify the sources and factors of competitive development of agricultural sector enterprises as a subject of economy in the conditions of institutional transformation of the Ukrainian economy.

According to Wikipedia information resource, geomarketing is a part of marketing research, it is a technology of decision making with the use of spatial data in the process of planning and implementation of activities in the field of marketing of products, management of spatial and distributed objects: consumers, competitive position and infrastructure of the territories ${ }^{11}$. Geomarketing research allows to diagnose external and internal geospatial indicators of agrarian enterprises, taking into account the dynamics and tendencies of development and to predict competitive behavior.

The author's interpretation of this category is as follows: geomarketing is a market-based concept of object management based on spatial research in order to improve the economic management of an enterprise to ensure its competitive development on the basis of an innovative component.

\footnotetext{
${ }^{11}$ URL: https://ru.wikipedia.org/wiki/Геомаркетинг
} 
Geomarketing is characterized by specific features that is determined by its object of study. The problems of territorial marketing are addressed in their researches by leading foreign and domestic scientists (P. Kotler, C. Hyder, I. Rein, J. Bowen and others) ${ }^{12}$. Thus, one of the most controversial issues in these studies is the development and definition of a set of geomarketing tools. P. Kotler indicates four key tools: product, price, promotion and marketing methods; R. Morris determines price, product, location, methods and people (this category includes manufacturers of products and their consumers).

According to Anderson, geographic marketing (geomarketing) is one of the most important components of geographic management that has its individual meaning. He divides the concept of geomarketing into three different concepts. Firstly, geomarketing can be understood as the geographical aspects of classic marketing, including the procedures for geographical segmentation of the market and the geographical positioning of goods. Secondly, geomarketing can be interpreted as location marketing and, in particular, region marketing. Thirdly, geomarketing can be seen as marketing of geographic knowledge and technology.

It is also worth noting the opinion of experts on the positioning of geomarketing as a general integrated concept, which should integrate all three above-mentioned approaches in order to establish synergistic links between the activities of geomarketing agents in the implementation of regional and local economic development of business entities, local authorities and the public. Such a comprehensive concept of geomarketing can be implemented through the organization of publicprivate partnerships at the regional and local levels.

Geomarketing is a technology of conducting market research for making strategic, conceptual and managerial decisions, based on the methods of geographical analysis of different spatial objects and phenomena. Such studies allow to identify the target audience in the right territorial unit, conduct a competitive analysis, determine the best location for a new store or pharmacy, forecast the turnover of commercial real estate, develop a concept for an existing or planned object, evaluate the best use of land and more.

Geomarketing is a technology for making strategic conceptual and managerial decisions regarding marketing researches, which are based on the use of methods of geographical analysis of spatially-distributed

\footnotetext{
${ }^{12}$ Tolstyakov R.R. (2015) Task and Instruments of Geomarketing. Social and Economic phenomena and progress, no. 12 , pp. 82-86.
} 
objects and phenomena. As a result, agricultural enterprises have a full range of information on the target consumer at the territorial unit, a complete analysis of the competitive position and information on segmentation of the market, the forecast of commercial efficiency and an assessment of the feasibility and prospects of their marketing policies. The experience of developed countries shows that there is a direct link between the competitiveness and the efficiency of the agro-marketing system. Thus, in the USA, for the qualitative and productive use of marketing tools, the state of infrastructure support, internal and external needs, their structure and volume, as well as the geolocation location of agrarian enterprise and its competitive position, are studied. The marketing strategy consists of managerial decisions, coordination of activities and internal policy of the economy, which is the most adaptable to the conditions of the functioning environment.

In the presence of a fairly blurred line between marketing and geomarketing, it is advisable to carry out the semantic characteristic of the concept of «geomarketing». The data in Table 1 give the possibility to establish a logical connection between the definitions, which is expressed in their consistent dependence, i.e. the latter is a derivative of the previous one.

Table 1

Semantic characteristics of the concepts of «geomarketing» and «marketing»

\begin{tabular}{|l|l|l|}
\hline \multicolumn{1}{|c|}{$\begin{array}{c}\text { Semantic } \\
\text { characteristics }\end{array}$} & \multicolumn{1}{|c|}{ Marketing } & \multicolumn{1}{c|}{ Geomarketing } \\
\cline { 2 - 3 } Methods & $\begin{array}{l}\text { Analysis, surveys, } \\
\text { observations }\end{array}$ & $\begin{array}{l}\text { Cartographic } \\
\text { comparative-geographical }\end{array}$ \\
\hline Means & $\begin{array}{l}\text { Product, price, methods } \\
\text { of promotion and } \\
\text { marketing promotion }\end{array}$ & $\begin{array}{l}\text { Price, location, product, } \\
\text { promotion, manufacturers } \\
\text { and consumers }\end{array}$ \\
\hline Practical value & $\begin{array}{l}\text { Developing and } \\
\text { implementting a } \\
\text { marketing action strategy } \\
\text { and improving the } \\
\text { efficiency of the } \\
\text { enterprise's marketing } \\
\text { activities }\end{array}$ & $\begin{array}{l}\text { Possibility of forecasting } \\
\text { competitive development } \\
\text { in the long term, taking } \\
\text { into account all spheres of } \\
\text { management }\end{array}$ \\
\hline Areas of study & $\begin{array}{l}\text { Integration into strategic } \\
\text { and tactical management }\end{array}$ & $\begin{array}{l}\text { Integration into the } \\
\text { information system }\end{array}$ \\
\hline
\end{tabular}




\begin{tabular}{|c|c|c|}
\hline \multirow{2}{*}{$\begin{array}{c}\text { Semantic } \\
\text { characteristics }\end{array}$} & \multicolumn{2}{|c|}{ Categories } \\
\hline & Marketing & Geomarketing \\
\hline Manageable object & Market relations & $\begin{array}{l}\text { Relations between } \\
\text { consumers, suppliers, } \\
\text { sellers, taking into account } \\
\text { the spatial component }\end{array}$ \\
\hline $\begin{array}{l}\text { Subjects of } \\
\text { relations }\end{array}$ & $\begin{array}{l}\text { Consumers, } \\
\text { manufacturers, } \\
\text { competitors }\end{array}$ & $\begin{array}{l}\text { Consumers, manufacturers, } \\
\text { competitors, developers, } \\
\text { executives }\end{array}$ \\
\hline Information space & Business activity & Integrated data system \\
\hline Purpose & $\begin{array}{l}\text { an indication of resource } \\
\text { efficiency in the current } \\
\text { period and the } \\
\text { achievement of strategic } \\
\text { objectives }\end{array}$ & $\begin{array}{l}\text { maximizing the economic } \\
\text { impact and ensuring } \\
\text { efficiency and } \\
\text { competitiveness in resource } \\
\text { management }\end{array}$ \\
\hline \multicolumn{3}{|c|}{ The essence of the concept } \\
\hline as a conception & $\begin{array}{l}\text { The art and science of } \\
\text { choosing a target market, } \\
\text { attracting, retaining, and } \\
\text { enhancing consumers } \\
\text { through the formation of } \\
\text { the consumer's idea of its } \\
\text { high value for the } \\
\text { enterprise. }\end{array}$ & $\begin{array}{l}\text { A market-based concept of } \\
\text { object management based } \\
\text { on spatial research in order } \\
\text { to improve the economic } \\
\text { management of an } \\
\text { enterprise to ensure its } \\
\text { competitive development } \\
\text { on the basis of an } \\
\text { innovative component. }\end{array}$ \\
\hline as a technology & $\begin{array}{l}\text { The activity is aimed at } \\
\text { achieving the goals of } \\
\text { enterprises, institutions, } \\
\text { organizations by } \\
\text { generating demand and } \\
\text { maximizing customer } \\
\text { satisfaction. }\end{array}$ & $\begin{array}{l}\text { The process of planning } \\
\text { and decision-making } \\
\text { regarding the pricing, } \\
\text { image and marketing } \\
\text { policy of the enterprise } \\
\text { using geoinformation } \\
\text { technologies. }\end{array}$ \\
\hline
\end{tabular}

With partial identity of marketing with geomarketing, it is advisable to analyze and evaluate the tools of geomarketing of agricultural enterprises represented at Figure 1. 


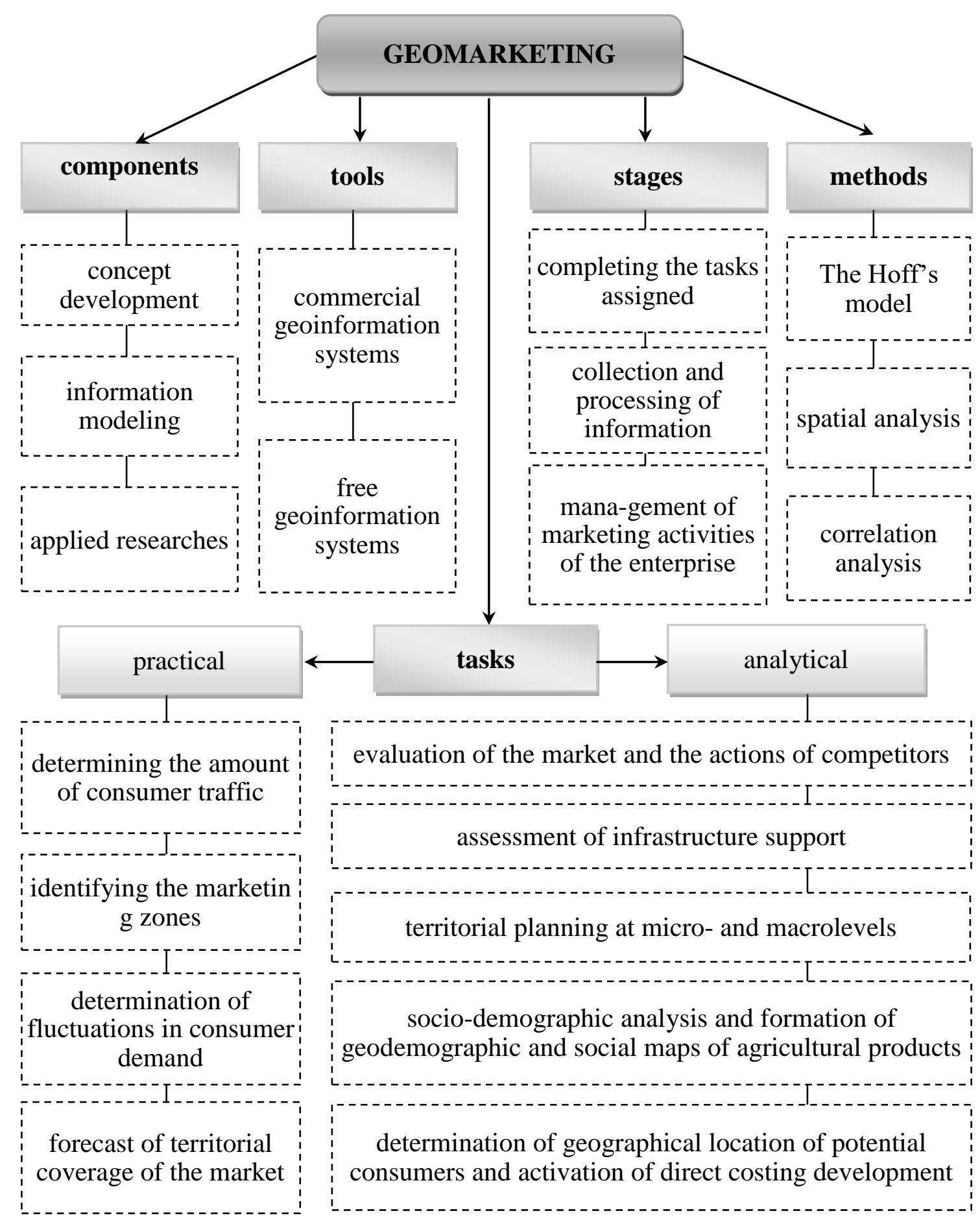

\section{Figure 1. Geomarketing tools for agricultural enterprises}

Methodological toolkit of geomarketing has its own unique specifics $^{13}$. Thus, spatial analysis allows forecasting and offering such product marketing options to reach as many consumers as possible,

\footnotetext{
13 Tolstyakov R.R. (2015). Task and Instruments of Geomarketing. Social and Economic phenomena and progress. No. 12, pp. 82-86.
} 
addresses the issue of reaching a given percentage of the total market share, taking into account competitors. Economic-statistical methods reveal correlation regression relationships and the degree and intensity of the influence of factors on the dependent variable. The Hoff's model allows to predict the estimated volume of consumer demand based on the geolocation of outlets or points of sale of products.

The main task of geomarketing is to establish optimal and most beneficial links between the manufacturer and consumers of products based on geolocation in order to maximize the positive effects. At the same time, geographical analysis of the environment can reduce economic costs, rationally allocate resources and make specific tactical managerial decisions. Taking into account spatial aspects reduces the number of mistakes that occur when conducting classic marketing research, avoiding mirroring and copying. It is inadmissible to directly transform the successful experience of other regions without taking into account the location of agrarian production, spatial component, etc. Thus, geomarketing as a synthesis of marketing and geography is a key component of ensuring competitive development and an element of generating competitive advantage at different levels. In addition, geoinformation technologies make it possible to visualize the spatially localized data obtained as a result of geomarketing research, which optimizes their work ${ }^{14}$.

Geomarketing complex is a set of geomarketing tools and methods used by an enterprise to achieve its market goals (Figure 2).

The information component is one of the most important tools for building a system of geoinformation activities in geomarketing of agricultural establishments, the basis for the formation of a favorable socially significant image of agricultural enterprises and their products. The main purpose of the geoinformation component is to comprehensively bring to the consumers of products information about the products of the enterprise, its environmental friendliness, safety and organic nature and the expediency of their acquisition. This is the guiding principle of informational and environmental activity in geomarketing. Environmental and organic trademarks and ecocertificates that can be awarded to businesses, products, and even terrain, are an effective tool for this.

\footnotetext{
${ }^{14}$ Andrianov V., Leonov A., Brekdyuk K. (2010). Geomarketing: na styike marketinga i geografi [Geomarketing: at the intersection of marketing and geography]. Marketing. Menedzhmen, no. 7-8.
} 




\section{Figure 2. Geomarketing complex of agricultural enterprises}

With the development of information technology, the improvement of the relevant infrastructure, the results of geomarketing research are becoming more accessible to end users, who are leaders at all levels and fields of activity. The use of a geomarketing approach is a guarantee for effective management of agricultural enterprises. Geomarketing as a powerful integrated tool is not effective at solving small specific problems. In these cases, it is more appropriate to use conventional marketing methods ${ }^{15}$.

It is possible to increase territory marketing efficiency by means of geomarketing methods, first of all, using geoinformation technologies, both at the stage of primary data collection and at the stage of forming a complex of marketing activities. Thus, it is possible to form such a new

15 Gorbunov I.N., Tolstyakov R.R. (2015). Informatsionnye sistemy geomarketinga [Information systems of geomarketing]. Vestnik nauchnykh konferentsij, no 1-7 (1), pp. 89-94. 
concept as "geomarketing of the territory», which should underlie the management of the development of the territory ${ }^{16}$.

When conducting geomarketing research, it is advisable for agricultural enterprises to use methods of construction of buffer zones, which allow to identify possible areas of market promotion, market coverage and its strength, to set priority directions of delivery and transportation of products. It is also advisable to use routing methods, accessibility analysis, and spatial statistics to ensure the latter This group of methods informs on the distribution of consumers, outlets, logistics centers, sales concentration, networking methods to reflect the relationships between manufacturers, resellers, sellers and buyers, identifying critical points and assessing the possibility of reducing noncritical paths and eliminating indirect links. A feature of geomarketing researches is their targeted use in managing the development of rural areas and intensifying the processes of their decentralization. The territorial community and the agricultural establishments, which are an element of its infrastructure, can carry out operational and strategic planning, project the development of the territories and adapt their infrastructures to the needs of the community and market environment, which is significant here. At the same time, the main goal of geomarketing research is to reduce the cost of product promotion and expansion of the internal and external market segment, as well as its maximum functionality (location/allocation). A feature of geomarketing is its adaptability to any enterprise management system and integration into its mechanisms. Classic marketing technology is based on the concept of four « $\left\langle\mathrm{P}^{\prime} \mathrm{s}\right\rangle$ : Product, Price, Place, Promotion, geomarketing strategy's focus is on Place and Market Outlet. Thus, in view of the existing interaction of the four factors, the location criterion has additional weight at the expense of the spatial component. This is important based on a number of circumstances: firstly, the heterogeneity of the structure of demand in space and, consequently, fluctuations in the volume of revenue, the number of economic relations and the structure of costs, secondly, the supply is also heterogeneous, that is there is a fluctuation in price with a standardized product, fragmentation of markets and other market fluctuations, thirdly, there is a certain mismatch of supply and demand and breaks in the logistics supply chain.

\footnotetext{
${ }^{16}$ Saulidi I.Yu. (2015). Geomarketing i marketing territorii: sootnoshenie ponyatiy [Geomarketing and territory marketing: a correlation of concepts]. Aktualnyie problemyi gumanitarnyih i estestvennyih nauk, no. 2 , pp. 37-39.
} 
Spatial development is not possible without the experience of the leading European countries. Geomarketing in the developed European countries in the agrarian sector of the economy has its characteristic features in the operating a product, price, marketing and communication policy. The most important and effective tool for engaging with consumers is the so-called regional trademark or brand. Its functional purpose is to support the positive image of the enterprise in the region, to create regional economic flows and value creation, to increase the «recognition» of products and to guarantee the quality of products, to increase the attractiveness for the consumer ${ }^{17}$. This experience is acceptable and can be adapted to agrarian enterprises in agrarian regions with high infrastructural potential and to the prospects of creating agroecological regions. The development and implementation of an agrarian regional trademark by enterprises as a result of a comprehensive geomarketing strategy will have a positive comprehensive effect. Firstly, it has a social, environmental and economic impact on the development of rural areas and agrarian entities, in particular. Secondly, it will help to stimulate the intensification and concentration of production in the agricultural sector, preserve jobs, partially overcome the effect of seasonality, increase economic turnover. Thirdly, it will improve the agricultural resource management system, improve the marketing of agricultural products, promote environmental management and regional self-identification.

\section{CONCLUSIONS}

The current state of enterprises of the agrarian sector of the economy of Ukraine is characterized by instability, stagnation, lack of effective management mechanisms, which necessitates the study of a number of issues related to the formation of an effective system of strategic management to ensure competitiveness in the global market environment. In the business practice, there is a relationship between the effectiveness of marketing activities of agricultural enterprises and increasing their competitiveness. The overwhelming majority of agricultural companies apply for only some marketing positions, without adapting leading foreign experience and achievements of leading domestic agricultural entities in the profuction activity. Given the conditions of doing business in a market environment, the essence of a

\footnotetext{
${ }^{17}$ Ivashov D.N. (2004). Ispolzovanie opyita regionalnogo marketinga v Evropeyskom Soyuze dlya ustoychivogo razvitiya selskih territoriy. URL: http://www.dissercat.com/content/ispolzovanie-opytaregionalnogo-marketinga-v-evropeiskom-soyuze-dlya-ustoichivogo-razvitiya-\#ixzz4OJC7PmUh
} 
marketing strategy can now be interpreted as defining the goals and objectives of the business entity-producer and exporter for each market segment and for each product line in accordance with the planned output. The company forms a marketing strategy on the basis of the study and analysis of the market situation, which is interesting for the manufacturer, its competitors, consumer requests. Defining a marketing strategy is to consider it as a process of activity based on key functions: formulating a mission, defining goals and familiarizing them with management and staff.

Geomarketing in the management of agricultural enterprises solves the following main tasks: determination of priority zones of development and sale of products; determination of the amount of consumer traffic and possible reasons for its fluctuations; to predict the extent of territorial coverage of the sales market and prevent it from overlapping with shopping areas. As a result, the main goal is achieved, namely: to increase economic efficiency based on space-time study of different starting conditions; monitoring, forecasting, management of agricultural establishments based on the detection of implicit patterns of consumer behavior in a dynamically changing environment. Geomarketing research tools allow investors and managers to get up-todate information to formulate development strategies, make tactical managerial decisions, substantiate concepts of diversification of production and marketing activities.

The advantages of microlevel geomarketing include: the ability to clearly illustrate the possibility of forming a stable infrastructure or trading network; selection of the optimal and efficient location of production and evaluation of its territorial expansion and diversification; evaluation of competitors in terms of determining the strength of connection and the intensity of competition; market valuation of the business and determining its future value, taking into account the geographical component. The advantages of the macrolevel are to ensure the balance of resource consumption, the optimal ratio between the number of points of sale and the volume of consumption and maximize the effect of «optimal location». It should be noted that limited access to source spatial, demographic and statistical data is a major obstacle to the application of a geomarketing strategy by agricultural establishments. Modern geomarketing makes it possible to carry out comprehensive studies of global and local economic processes, which is very important for the spatial economy. 
Therefore, geomarketing is an innovative tool for analysis and management, resulting in an information resource, which is the basis for managerial decision-making. Geomarketing uses: geodata, which is a system information resource that allows to apply methods of system analysis effectively; spatial relationships that take into account spatial factors of economic characteristics; innovations in the management of agricultural enterprises.

\section{SUMMARY}

The role and place of geomarketing in the management system of agrarian enterprises are determined, on the basis of generalization of scientific approaches to concepts the essence and features of geomarketing, its tools, components and tasks are determined. The necessity of forming an effective system of strategic management of agricultural establishments, including an adaptive strategy of ensuring competitiveness, which would take into account the specificity and needs of agricultural sector enterprises and is a priority task in their management is proved. The necessity to consider the spatial component in the implementation of the marketing strategy is determined. The need to create a unified information environment for the management of spatially distributed resources in order to ensure economic growth and competitive development is also disclosed. As a result, the theoretical approaches were generalized, the geomarketing tools were systematized and formed, the semantic characteristics of the definitions of «marketing» and «geomarketing» were conducted, the priority tasks of geomarketing were determined and the possibilities of its application in the management system of agricultural enterprises were evaluated.

\section{REFERENCES:}

1. Anderson V.M. (2005). Heomenedzhment i heomarketynh yak instrumenty staloho rozvytku $\mathrm{v}$ umovakh konkurentsii rehioniv [Geo-management and geomarketing as tools for sustainable development in conditions of regional competition]. Naukovyi visnyk, no. 15.7, pp. 225-231.

2. Andrianov V., Leonov A., Brekdyuk K. (2010). Geomarketing: na styike marketinga i geografi [Geomarketing: at the intersection of marketing and geography]. Marketing. Menedzhmen, no. 7-8.

3. Bagrov N.V. (2002). Regionalnaya geopolitika ustoychivogo razvitiya [Regional geopolitics of sustainable development]. Kiev: Lyibid, 256 p. 
4. Bilorus O.H., Matseiko Yu.M. (2005). Hlobalna perspektyva i stalyi rozvytok: Systemni marketolohychni doslidzhennia [A global perspective and sustainable development: system market research]. Kyiv: MAUP, 492 p.

5. Borshchuk Ye.M. (2007). Osnovy teorii stiikoho rozvytku ekoloho-ekonomichnykh system: Monohrafiia [Fundamentals of the theory of sustainable development of ecological and economic systems: Monograph]. Lviv: Rastr-7, 435 p.

6. Butenko N.V. Osnovy marketynhu: pidruchnyk [Marketing Basics: Tutorial]. URL: http://books.efaculty.kiev.ua/mrk/3

7. Herasymchuk Z.V., Vakhovych I.M. (2002). Orhanizatsiinoekonomichnyi mekhanizm formuvannia ta realizatsii stratehii rozvytku rehionu: Monohrafiia [Organizational and economic mechanism of formation and implementation of the regional development strategy: Monograph]. Lutsk: LDTU, 248 p.

8. Danylyshyn B. (2008). Formuvannia tsilisnoi natsionalnoi hospodarskoi systemy: sotsioloho-ekonomichni aspekty [The formula of the cospilial national hospodar system: socio-economic aspects]. Visnyk NAN Ukrainy, no. 7, pp. 3-11.

9. Ivashov D.N. (2004). Ispolzovanie opyita regionalnogo marketinga $\mathrm{v}$ Evropeyskom Soyuze dlya ustoychivogo razvitiya selskih territoriy [Using the experience of regional marketing in the European Union for sustainable rural development]. URL: http://www.dissercat.com/content/ispolzovanie-opyta-regionalnogomarketinga-v-evropeiskom-soyuze-dlya-ustoichivogo-razvitiya\#ixzz4OJC7PmUh

10. Mazniev H.Ie. (2011). Heoinformatsiini tekhnolohii v ahrarnomu vyrobnytstvi [Geoinformation technologies in agricultural production]. Ekonomika APK, no. 4, pp. 130-136.

11. Makhnusha S.M Pidkhody do stymuliuvannia staloho rozvytku rehioniv na zasadakh heomenedzhmentu ta heomarketynhu [Approaches to stimulating sustainable development of regions based on geomanagement and geomarketing]. URL: http://zavantag.com/ docs/427/index-2023587.html?page=18\#977151

12. Saulidi I.Yu. (2015). Geomarketing i marketing territorii: sootnoshenie ponyatiy [Geomarketing and territory marketing: a correlation of concepts]. Aktualnyie problemyi gumanitarnyih $i$ estestvennyih nauk, no. 2, pp. 37-39. 
13. Iurchenko O.A. (2010). Perevahy vykorystannia marketynhu na pidpryiemstvakh APK [Advantages of using marketing at agricultural enterprises]. Marketynh v Ukraini, no. 2, pp. 22-30.

14. Gorbunov I.N., Tolstyakov R.R. (2015). Informatsionnye sistemy geomarketinga [Information systems of geomarket-ing]. Vestnik nauchnykh konferentsij, no. 1-7 (1), pp. 89-94.

15. Nesi P., Pantaleo G., Tenti M. (May 2016). Geographical localization of web domains and organization addresses recognition by employing natural language processing, Pattern Matching and clustering. Engineering Applications of Artificial Intelligence Mining the Humanities: Technologies and Applications, V. 51, pp. 202-211.

16. Tolstyakov R.R. (2015). Task and Instruments of Geomarketing. Social and Economic phenomena and progress, no. 12, pp. 82-86.

17. URL: https://ru.wikipedia.org/wiki/Геомаркетинг

Information about the author: Hranovska V. H.

Doctor of Economic sciences, Associate Professor, Senior Lecturer of Hotel-Restaurant and Tourism Business Department, SHEI «Kherson State Agrarian University», Ukraine ORCID: https://orcid.org/0000-0003-0348-9692 